\title{
Primordium of the Liver
}

National Cancer Institute

\section{Source}

National Cancer Institute. Primordium of the Liver. NCI Thesaurus. Code C34277.

The cephalic portion of the hepatic diverticulum that invades the septum transversum during the third week of embryonic development, and which forms the parenchyma of the liver, while the hemopoietic cells, the Kupffer cells, and the connective tissue of the liver are derived from mesenchyme in the septum transversum. 